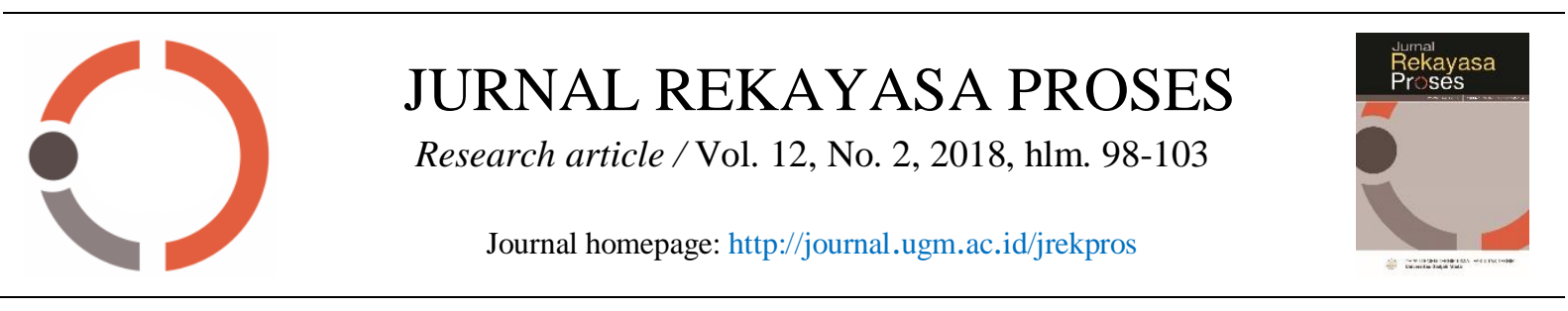

\title{
Aplikasi Koagulan Biji Asam Jawa dalam Penurunan Konsentrasi Zat Warna Drimaren Red pada Limbah Tekstil Sintetik pada Berbagai Variasi Operasi
}

\author{
Angela Martina ${ }^{1 *}$, Dian Santoso Effendy ${ }^{1}$ dan Jenny Novianti M. Soetedjo ${ }^{1}$ \\ ${ }^{1}$ Program Studi Teknik Kimia, Fakultas Teknologi Industri, Universitas Katolik Parahyangan \\ Jalan Ciumbuleuit 94, Bandung, Indonesia \\ *Alamat korespondensi: angela.martina@unpar.ac.id
}

(Submisi 20 September 2018 ; Revisi 18 November 2018 ; Penerimaan 22 November 2018)

\section{A B S T R A C T}

Since textile industries use a lot of water in their processes, a huge volume of waste water containing dyes are produced by the increase of the production capacity. Coagulation and flocculation are the common processes applied since they can effectively decrease the dye concentration in the waste water. These treatments usually utilize chemical coagulant and flocculant which are expensive and non-biodegradable. In this research, tamarind seed as one of biobased-coagulants was studied and developed to reduce drimaren dark red HF-CD concentration which is used widely in textile industry in the synthetic waste water. The research was designed using Design Expert 7.0.0, Central Composite Design with range of variables as follows: $\mathrm{pH}$ (2-7), tamarind seed concentration (1-3 g/L), and dye concentration (20-30 ppm). The result shows a promising application of natural coagulant up to $94.25 \%$ decrease of dye concentration in the optimum condition of $3.68 \mathrm{~g} / \mathrm{L}$ tamarind seed concentration, 25 ppm dye concentration and $\mathrm{pH}$ value of 4.5 .

Keywords: coagulation; dye concentration acid; natural coagulant; tamarind seeds.

\begin{abstract}
A B S T R A K
Industri tekstil merupakan industri yang banyak menggunakan air dalam proses produksinya sehingga menghasilkan limbah yang mengandung zat warna tekstil dengan volume yang besar. Pengolahan yang umum digunakan untuk mengolah limbah tekstil ini adalah koagulasi dan flokulasi. Metode ini efektif dalam mengurangi konsentrasi zat warna pada air limbah. Koagulan yang digunakan pada penelitian ini adalah koagulan alami yang terbuat dari biji asam jawa. Penelitian ini bertujuan untuk mengetahui kemampuan dan kondisi optimum biji asam jawa sebagai koagulan alami dalam menurunkan konsentrasi zat warna pada limbah tekstil. Limbah tekstil yang digunakan merupakan limbah sintetik zat warna drimaren dark red HF-CD. Rancangan penelitian dibuat menggunakan Design Expert 7.0.0 metode central composite design dengan memvariasikan variabel $\mathrm{pH}$ (2-7), dosis koagulan $(1-3 \mathrm{~g} / \mathrm{L})$, dan dosis zat warna $(20-30 \mathrm{ppm})$. Kondisi terbaik yang didapat dari penelitian diperoleh pada $\mathrm{pH} 4,5$, dosis koagulan $3,68 \mathrm{~g} / \mathrm{L}$, dosis zat warna $25 \mathrm{ppm}$ dengan hasil persen penurunan konsentrasi zat warna sebesar $94,29 \%$.
\end{abstract}

Kata kunci: biji asam jawa; koagulasi; koagulan alami; konsentrasi zat warna 


\section{Pendahuluan}

Air adalah sumber daya yang diperlukan oleh semua makhluk hidup dan tidak dapat digantikan oleh bahan yang lain. Pada skala besar, air banyak digunakan pada kegiatan industri seperti sebagai bahan pencuci, pendingin, pembangkit listrik, dan bahan baku. Salah satu industri yang banyak menggunakan air adalah industri tekstil (Ghaly et al., 2014). Seperti ditunjukkan pada Tabel 1, industri tekstil di Indonesia masih mengalami perkembangan walaupun sedikit lambat.

Berkembangnya industri tekstil di Indonesia membuat produk tekstil yang dihasilkan juga meningkat. Hal ini tentu akan meningkatkan jumlah limbah yang dihasilkan pada tiap prosesnya. Proses-proses di dalam industri tekstil meliputi sizing (pelapisan benang), desizing (pemurnian), proses bleaching (pemutihan), mercerizing (perlakuan terhadap larutan alkali), dyeing (pewarnaan), printing (pencetakan), dan pengerasan produk tekstil (seperti kain, benang, atau barang jadi) (Patel, 2015) . Dari berbagai proses yang ada pada industri tekstil, polusi limbah industri tekstil berasal dari proses dyeing dan printing yang menghasilkan $\pm 15 \%-20 \%$ dari total air limbah tekstil dan banyak mengandung zat warna (Savin, 2008).

Tabel 1. Performa tekstil Indonesia (Maizer, 2018)

\begin{tabular}{lccc}
\hline & 2015 & 2016 & 2017 \\
\cline { 2 - 4 } Kapasitas (ton) & 2420 & 2450 & 2450 \\
Produksi (ton) & 1833 & 1951 & 2082 \\
Penjualan produk lokal (ton) & 1286 & 1401 & 1557 \\
Konsumsi (ton) & 1878 & 1878 & 2021 \\
Pangsa pasar lokal & $68,5 \%$ & $74,6 \%$ & $77 \%$ \\
Konsumsi berdasarkan PDB & & & \\
(Produk Domestik Bruto) & 7.710 & 8.326 & 9.024 \\
(Rp.triliun) & & & \\
\hline
\end{tabular}

Untuk menghilangkan kandungan zat warna dari proses dyeing dan printing diperlukan metode pengolahan limbah. Metode pengolahan zat warna yang banyak pada industri adalah koagulasi-flokulasi dan adsorpsi. Metode pengolahan yang dipilih pada penelitian ini adalah koagulasi-flokulasi karena metode ini efektif dalam mengurangi konsentrasi zat warna (Bratby, 2006; Antov, 2012).
Koagulasi merupakan proses pengolahan air limbah dengan mendestabilisasikan partikel koloid, sedangkan flokulasi merupakan proses lanjutan koagulasi di mana partikel yang terdestabilisasi akan membentuk partikel yang lebih besar. Terdapat 4 metode destabilisasi partikel pada koagulasi-flokulasi yaitu double layer compression, charge neutralization, entrapment precipitate, dan particle bridging. Metode koagulasi-flokulasi sendiri juga dipengaruhi oleh beberapa faktor seperti jenis koagulan, dosis koagulan, $\mathrm{pH}$, dan kecepatan pengadukan. Faktor-faktor ini akan mempengaruhi keefektifan proses koagulasiflokulasi. Pada proses koagulasi flokulasi diperlukan penambahan suatu zat yang membantu proses pengendapan partikel yang disebut sebagai koagulan. Koagulan akan membentuk partikel-partikel besar yang kemudian akan mengendap. Partikel besar ini disebut sebagai flok (Howe et al., 2012; Wahyuni dkk., 2016). Berdasarkan jenisnya koagulan terdiri atas 2 jenis yaitu koagulan kimia dan koagulan alami. Koagulan kimia merupakan koagulan yang menggunakan bahan-bahan kimia yang umumnya mengandung logam. Dewasa ini, penelitian berkembang pada pembuatan dan penggunaan koagulan alami yang berasal dari sumber daya alam terbaharui seperti tanaman, hewan, atau bahkan dari mikroorganisme.

Tabel 2. Komposisi Biji Asam Jawa (Kumar et.al., 2008)

\begin{tabular}{lcc}
\hline Komponen & Inti Biji (\%) & Kulit biji (\%) \\
\hline Kelembaban & $11,4-22,7$ & 11,0 \\
Protein & $15,0-20,9$ & - \\
Lemak/minyak & $3,9-16,2$ & - \\
Serat kasar & $2,5-8,2$ & 21,6 \\
Karbohidrat & $65,1-72,2$ & - \\
Ash Contain & $2,4-4,2$ & 7,4 \\
Gula Pereduksi & - & - \\
Tanin & - & 20,2 \\
\hline
\end{tabular}

Pada penelitian ini digunakan koagulan berbasis biomassa yang lebih ramah lingkungan dan biodegradable. Biomassa yang dapat digunakan sebagai koagulan adalah biji kelor (Moringa oleifera), biji pepaya (Carica papaya), biji kecipir (Psophocarpus tetragonolobus), dan biji asam jawa (Tamarindus indica) (Mishra, 
2006; Soetedjo dkk., 2017a; Soetedjo dkk., 2017b). Pemilihan biji asam jawa (Tamarindus indica) sebagai bahan baku pembuatan koagulan alami pada penelitian ini didasarkan pada tujuan untuk meningkatkan nilai guna biji asam jawa yang hingga saat ini belum termanfaatkan. Biji asam jawa sendiri terdiri dari kulit biji (20-30\%) dan endosperm (70-75\%) (Kumar et al., 2008; El-Siddig et al., 2006). Biji asam jawa dapat menjadi koagulan karena adanya kandungan protein, pati (karbohidrat), dan tanin. Pada Tabel 2 dapat dilihat komposisi kandungan biji asam jawa.

Kandungan protein dan tanin pada asam jawa berperan menjadi polielektrolit alami yang mirip dengan koagulan kimia. Polielektrolit berfungsi untuk mempermudah terbentuknya flok. Protein sendiri dapat memiliki muatan positif atau negatif dengan proses pengendapan pada umumnya memanfaatkan proses tarik-menarik antar muatan. Secara umum proses koagulasi menggunakan koagulan alami termasuk ke dalam mekanisme koagulasi particle bridging dan/atau charge neutralization (Andre dkk., 2015)].

Penelitian berkaitan dengan pemanfaatan biji asam jawa sebagai koagulan alami masih terus dikembangkan hingga saat ini. Pada penelitian terdahulu (Soetedjo dkk., 2017a), asam jawa dapat digunakan sebagai koagulan alami untuk menurunkan konsentrasi zat warna hingga $84 \%$, namun belum diketahui kondisi optimum untuk proses koagulasinya. Penelitian ini berfokus pada penentuan kondisi optimum proses koagulasi menggunakan koagulan biji asam jawa dalam menurunkan konsentrasi zat warna drimaren dark red $H F-C D$.

\section{Metode Penelitian}

Bahan baku yang digunakan pada penelitian ini adalah biji asam jawa didapat dari UD. Benih Mandiri, Yogyakarta. Sebagai persiapan awal, biji asam jawa direndam selama 1-2 hari untuk mempermudah pengupasan kulit biji dan kemudian dikeringkan menggunakan oven hingga kandungan air pada biji kurang dari $10 \%$. Setelah dikeringkan, biji asam jawa dikecilkan ukurannya menggunakan blender dan diayak hingga diperoleh ukuran -70+100 mesh. Larutan limbah tekstil industri diwakilkan dengan larutan sintetik yang terbuat dari drimaren dark red $\mathrm{HF}$ $C D$. Zat warna drimaren red adalah pewarna reactive yang merupakan salah satu pewarna utama untuk mewarnai serat yang mengandung polisakarida. Selanjutnya penelitian utama dilakukan berdasarkan rancangan yang dapat dilihat pada Tabel 3. Proses koagulasi dilakukan dalam gelas kimia yang dilengkapi dengan paddle pada kondisi suhu ruang dengan kecepatan pengadukan $200 \mathrm{rpm}$ selama 5 menit dilanjutkan $60 \mathrm{rpm}$ selama 30 menit kemudian proses pengendapan dilakukan selama 1 jam. Analisis penurunan konsentrasi zat warna dilakukan menggunakan metode spektrofotometri.

\section{Hasil dan Pembahasan}

Untuk keperluan analisis penurunan konsentrasi zat warna menggunakan spektrofotometer, panjang gelombang maksimum drimaren red dicari pada rentang 400-580 $\mathrm{nm}$. Panjang gelombang maskimum diperoleh pada $526 \mathrm{~nm}$. Kurva standar dibuat pada panjang gelombang maksimum dan diperoleh persamaan $y=0,0307 x$ dengan y adalah nilai absorbansi dan $\mathrm{x}$ adalah konsentrasi larutan. Korelasi ini memberikan nilai $R$-Squared sebesar 0,9968.

Hasil penelitian dapat dilihat pada Tabel 3. Berdasarkan Tabel 3, proses koagulasi pada $\mathrm{pH}$ 4,5, dosis koagulan 3,68 g/L, dan dosis zat warna 25 ppm menghasilkan penurunan konsentrasi zat warna maksimum yaitu 94,29\%. Data penurunan konsentrasi zat warna digunakan sebagai respon untuk perhitungan anova.

Hasil anova memberikan pengaruh yang signifikan pada model dengan nilai $R$-Squared, adj $R$ Squared, dan preR-Squared secara berurutan adalah 0,9212; 0,8502; dan 0,4011. Dengan data yang diinput pada Design Expert, didapat grafik 3D seperti pada Gambar 1 dan Gambar 2. 
Tabel 3. Hasil percobaan penelitian

\begin{tabular}{cccc}
\hline $\mathrm{pH}$ & $\begin{array}{c}\text { Dosis } \\
\text { Koagulan } \\
(\mathrm{g} / \mathrm{L})\end{array}$ & $\begin{array}{c}\text { Dosis } \\
\text { Zat } \\
\text { Warna } \\
(\mathrm{ppm})\end{array}$ & $\begin{array}{c}\text { Penurunan } \\
\text { Konsentrasi Zat } \\
\text { Warna (\%) }\end{array}$ \\
\hline 4,5 & 2 & 25 & 93,54 \\
2,0 & 3 & 20 & 71,18 \\
7,0 & 1 & 20 & 68,13 \\
4,5 & 2 & 25 & 92,38 \\
4,5 & 2 & 25 & 93,21 \\
4,5 & 3,68 & 25 & 94,29 \\
8,7 & 2 & 25 & 57,51 \\
4,5 & 0,32 & 25 & 91,24 \\
4,5 & 2 & 33,41 & 93,85 \\
2,0 & 1 & 20 & 61,19 \\
7,0 & 1 & 30 & 71,12 \\
7,0 & 3 & 20 & 80,32 \\
4,5 & 2 & 16,59 & 90,73 \\
4,5 & 2 & 25 & 93,18 \\
4,5 & 2 & 25 & 93,04 \\
2,0 & 3 & 30 & 75,28 \\
0,3 & 2 & 25 & 61,42 \\
2,0 & 1 & 30 & 72,92 \\
7,0 & 3 & 30 & 81,66 \\
4,5 & 2 & 25 & 92,68 \\
\hline & & & \\
& & & \\
\hline
\end{tabular}

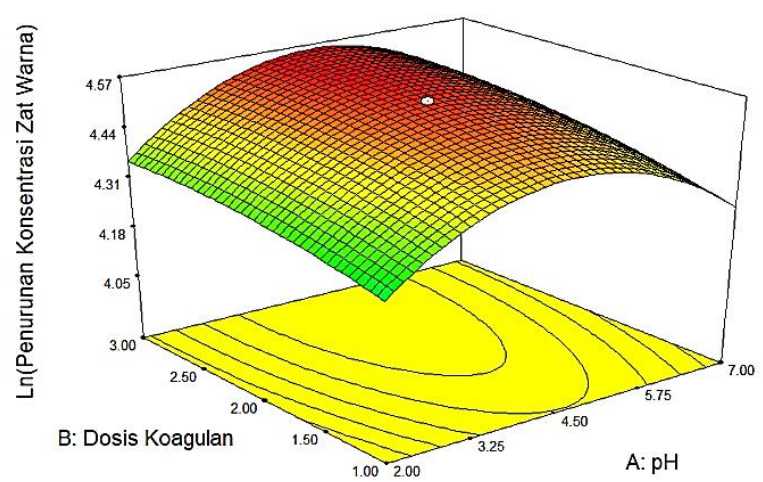

Gambar 1. Pengaruh pH dan dosis koagulan

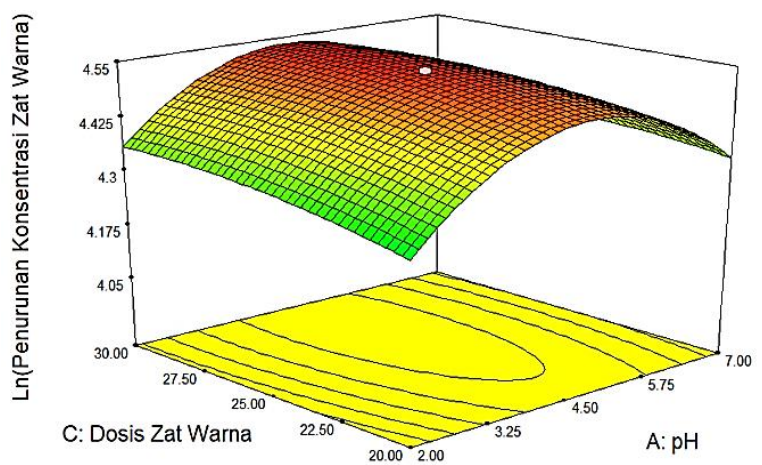

Gambar 2. Pengaruh pH dan dosis zat warna

Berdasarkan Gambar 1, pada bagian $\mathrm{pH}$ terlihat bentuk kubah melengkung ke atas sehingga didapatkan titik optimum $\mathrm{pH}$ dalam \% penurunan konsentrasi zat warna, yaitu pada $\mathrm{pH}$ 4,5 namun pada bagian dosis koagulan masih memiliki kecenderungan data naik keatas sehingga belum dapat ditentukan dosis koagulan yang optimum. Pada Gambar 2 dosis zat warna juga memiliki kecenderungan data yang sama dengan dosis koagulan sehingga belum dapat ditentukan dosis yang optimum untuk zat warna. Berdasarkan data hasil penelitian, design expert memberikan 30 data yang diindikasikan sebagai titik optimum. Penelitian lanjutan masih perlu dilakukan pada rentang dosis koagulan dan dosis zat warna yang lebih besar untuk mendapatkan titik optimum proses koagulasi.

\subsection{Pengaruh pH terhadap \% Penurunan Zat Warna}

Zat warna drimaren red akan menghasilkan ion negatif saat dilarutkan di dalam air sedangkan protein dari asam jawa mengandung ion positif $\left(\mathrm{H}^{+}\right)$saat berada pada $\mathrm{pH}$ asam. Berdasarkan Gambar 3 terlihat \% penurunan konsentrasi terbesar diperoleh pada $\mathrm{pH} 4,5$ dengan $\%$ penurunan sebesar $90,03 \%$.

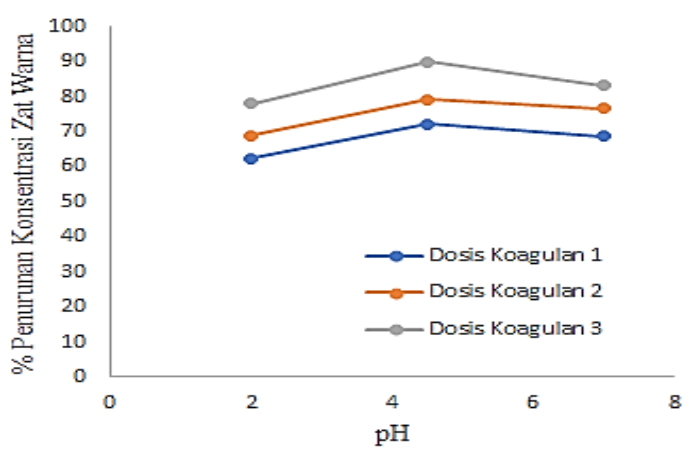

Gambar 3. Pengaruh pH terhadap \% penurunan konsentrasi zat warna

Pada $\mathrm{pH} 2$, kandungan $\mathrm{H}^{+}$pada larutan zat warna lebih banyak dibandingkan pada $\mathrm{pH} 4,5$ dan 7. Hal ini mengakibatkan terjadinya gaya tolak-menolak antara protein dengan ion positif. Sedangkan pada $\mathrm{pH}$ 4,5 kandungan ion $\mathrm{H}^{+}$dan $\mathrm{OH}^{-}$yang terkandung cukup seimbang sehingga ion-ion di dalam larutan akan saling berikatan dan menyebabkan mekanisme charge neutralization. Setelah terjadi mekanisme charge neutralization biasanya diikuti dengan particle bridging. Proses ini dapat terjadi karena adanya 
gaya Van der Waals (Anonim, 2014; Mishra et al., 2005).

\subsection{Pengaruh dosis koagulan terhadap \%} penurunan zat warna

Pengaturan dosis koagulan dapat memberikan pengaruh koagulasi yang maksimal. Berdasarkan hasil penelitian pada Gambar 4 terjadi kenaikan $\%$ penurunan konsentrasi zat warna pada berbagai $\mathrm{pH}$. Koagulasi terbaik terjadi pada $\mathrm{pH}$ 4,5 dan dosis koagulan $3 \mathrm{~g} / \mathrm{L}$ dengan $\%$ penurunan konsentrasi zat warna sebesar $89,95 \%$ dan masih memiliki kencenderungan data meningkat yang memungkinkan memberikan \% penurunan konsentrasi zat warna yang lebih besar. Peningkatan ini dapat disebabkan karena masih adanya zat warna yang belum terikat oleh koagulan sehingga penambahan dosis koagulan akan mampu mereduksi zat warna dan meningkatkan $\%$ penurunan konsentrasi zat warna.

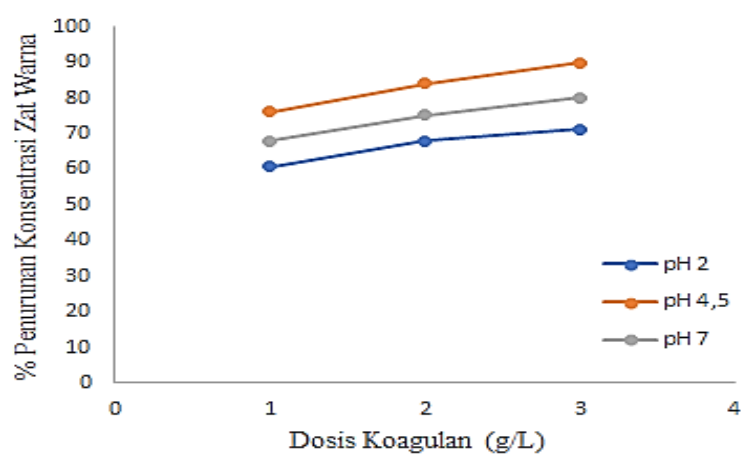

Gambar 4. Pengaruh dosis koagulan terhadap \% penurunan konsentrasi zat warna

\subsection{Pengaruh dosis zat warna terhadap \%} penurunan zat warna

Pada zat warna terdapat gugus polimer yang memberikan warna pada larutan zat warna. Penanganan tertentu terhadap gugus polimer ini dapat mempengaruhi struktur polimer zat warna itu sendiri. Supaya proses koagulasi dapat berjalan secara efektif, diharapkan zat warna memiliki gugus kimia yang dapat berikatan dengan koagulan membentuk flok. Berdasarkan Gambar 5 dan 6 semakin tinggi dosis zat warna maka semakin tinggi \% penurunan konsentrasi zat warna. Hal ini disebabkan karena koagulan yang digunakan masih memiliki kemampuan untuk menyerap zat warna yang masih terkandung di dalam larutan limbah sintetik.

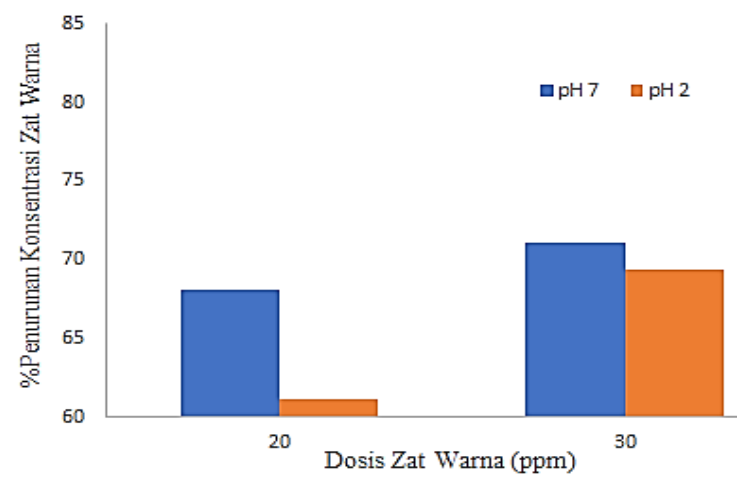

Gambar 5. Pengaruh dosis zat warna terhadap \% penurunan konsentrasi zat warna pada dosis koagulan $1 \mathrm{~g} / \mathrm{L}$

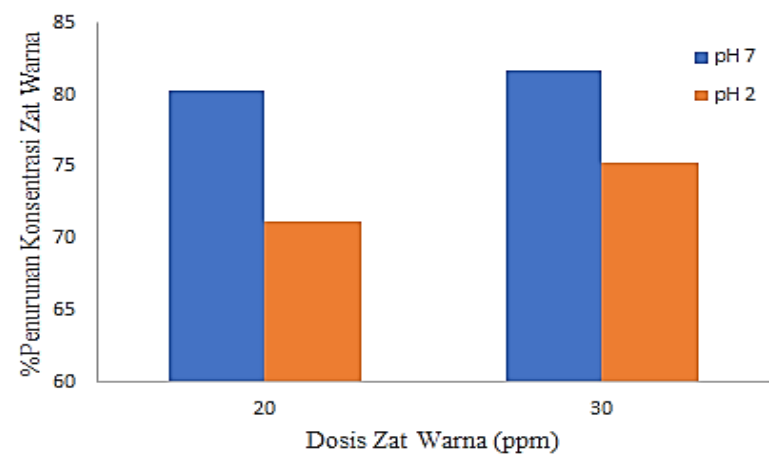

Gambar 6. Pengaruh dosis zat warna terhadap \% penurunan konsentrasi zat warna pada dosis koagulan $3 \mathrm{~g} / \mathrm{L}$

\section{Kesimpulan}

Biji asam jawa dapat dimanfaatkan sebagai koagulan alami yang mampu menurunkan konsentrasi zat warna. Semakin tinggi konsentrasi zat warna dan dosis koagulan yang digunakan akan semakin tinggi pula \% penurunan konsentrasi zat warna. Koagulan biji asam jawa memberikan penurunan konsentrasi tertinggi pada $\mathrm{pH}$ 4,5 dan dosis koagulan 3,68 $\mathrm{g} / \mathrm{L}$ dengan $\%$ penurunan zat warna sebesar $94,29 \%$.

\section{Daftar Pustaka}

Andre, A., Wardhana, I.W., dan Sutrisno, E., 2015, Penggunaan tepung biji asam jawa (Tamarindus indica) sebagai biokoagulan untuk menurunkan kadar fosfat dan cod pada 
air limbah usaha laundry, Jurnal Teknik Lingkungan, 4 (4), 1-5

Anonim, 2014, World Dye Variety, Available at www.worlddyevariety.com/reactive dyes/reactive-red-123.html. [Diakses 31 July 2018].

Antov, M.G., Šćiban, M.B. dan Prodanović, J.M., 2012, Evaluation of the efficiency of natural coagulant obtained by ultrafiltration of common bean seed extract in water turbidity removal, Ecological Engineering, 49, 48-52

Bratby, J., 2006, Coagulation and Flocculation in Water and Wastewater Treatment, IWA Publishing, London

El-Siddig, K., Gunasena, H.P.M., Prasad, B.A., Pushpakumara, Ramana, K.V.R., Vijayanand, P. and Williams, J.T., 2006, Tamarind Tamarindus indica L., RPM Print and Design, W. Sussex, England

Ghaly, A.E., Ananthaskar, R, dan Alhattab, M., 2014, Production, characterization and treatment of textile effluents: A critical review, J. Chem. Eng. Process. Technol., 5 (1), 1-18

Howe, K.J., Hand, W., David, Jhon, C., Rhodes, R., dan George, T., 2012, Principle of Water Treament, John Wiley \& Sons, Inc., Hoboken, New Jersey

Kumar, C.S., dan Bhattacharya, S., 2008, Tamarind seed: properties, processing and utilization, Crit. Rev. Food Sci. Nutr., 48, 120

Mishra, Anuradha, Bajpai dan Malvika, 2005, Flocculation behaviour of model textile wastewater treated with a food grade polysaccharide, J. Hazard. Mater.,118 (1-3), 213-217.

Mishra, A. dan Bajpai, M., 2006, The flocculation performance of tamarindus mucilage in relation to removal of vat and direct dyes, Bioresour. Technol., 97 (8), 10551059
Maizer, 2018, Indotextile, CV. Gaindo Pratama Indonesia., [Online]. Available: http://www.indotextiles.com/index.php?optio $\mathrm{n}=$ com_content $\&$ task=view\&id=5147.

[Diakses 30 July 2018]

Patel, H.R.V., 2015, Characterization and Treatment of Textile Wastewater, Elsevier, USA

Savin B.R., 2008, Wastewater characteristics in textile finishing mills, Environ. Eng. Manage. J., 7 (6), 859-864

Soetedjo J., Kristianto H. dan Handriono C., 2017a, Kajian Penggunaan Biji Asam Jawa (Tamarindus Indica) sebagai Koagulan Alami dalam Pengolahan Limbah Cair Tekstil Sintetik, Universitas Katolik Parahyangan, Bandung

Soetedjo J., Kristianto H. dan Kurniawan M., 2017b, Kajian Penggunaan Biji Pepaya (Carica Papaya L.) sebagai Koagulan Alami dalam Pengolahan Berbagai Jenis Air Limbah, Universitas Katolik Parahyangan, Bandung

Wahyuni S., Siswanto dan Akbar G., 2016, Kitosan Sebagai Koagulan dan Flokulan pada Proses Pre-Treatment Limbah Cair Kelapa Sawit," [Online]. Available: iribb.org/ index.php?option=com_content $\&$ view $=$ article \&id=295:kitosan-sebagai-koagulan-danflokulan-pada-proses-pre-treatment-limbahcair-kelapa-sawit\&catid=2:berita\&Itemid= 12 . [Diakses 16 September 2017]. 